\begin{tabular}{c} 
International Journal of Engineering \& Technology, $7(3.21)(2018) 317-320$ \\
International Journal of Engineering \& Technology \\
SPC \\
Website: $\frac{w w w . s c i e n c e p u b c o . c o m / i n d e x . p h p / I J E T}{2}$ \\
Research paper \\
\hline
\end{tabular}

\title{
Exixtence of Indonesian Advocate Profession
}

\author{
M. Zamroni ${ }^{1}$ \\ ${ }^{I}$ Department of Law, Universitas Maarif Hasyim Latif, Sidoarjo, Indonesia. \\ *Corresponding author E-mail: zamronilawoffice@gmail.com / zamroni@dosen.umaha.ac.id
}

\begin{abstract}
Hope to have legislation that specifically set while an umbrella in running materialize advocate profession, lawyers are more confident in addition to other law enforcement officials, such as judges, prosecutors and police, as well as respected as an equal partner in the law enforcement process. But the big question is how the existence of the profession of advocate Indonesia before and after the enlawment of Act Number 18 of 2003 concerning the Advocate, as well as any constraints that occur in their implementation. The rule of law relating to the profession of advocate before the enLawment of Act Number 18 of 2003 concerning The Advocate, scattered in various laws, such as Act Number 1 of 1946 on the Law of Criminal Code, Act Number 1 of 1950 on the Supreme Court, Emergency Act Number 1 of 1951 governing temporary measures to organize the unity of the pecking order and civil court events, and Herziene Indlandsch Regalement (HIR). Before the release of Act Number 18 of 2003 concerning Advocates, advocate the use of the term in prLawice there has been no standard for the profession. In various provisions of the legislation of any inconsistency pr. For example Act Number 14 of 1970 , as has been replaced by Act Number 35 of 1999, and was replaced again by Act Number 4 of 2004 as well as the latter is replaced by Act Number 48 of 2009, regarding the power of Justice, to use the term legal aid and lawyers. Birth of the Act of the Republic of Indonesia Number 18 of 2003 concerning The Advocate is the expectation of a long delayed during the 58 years since the independence of the Republic of Indonesia, the laws governing the profession of advocate a free, independent and responsible for the implementation of a judicial honest, fair, and legal certainty for all seekers of justice in upholding the law, truth, justice, and human rights.
\end{abstract}

Keywords: Advocate Organization; Advocate Profession; Law

\section{Introduction}

Advocate profession is regarded as a noble profession (officium nobile). It upholds the rule of law and justice in addition to the legal profession to another, play an Lawive role in the formal legal process in air-show in court and the non-litigation out of court, in addition to the most important thing is to uphold the moral values and the search for justice in a continuous process that never stops $(1,2)$. The existence of professional advocate is a necessity in the Republic of Indonesia (3). In the 1945 Constitution, it states that the Republic of Indonesia is a State of Law, and therefore, every citizen has equal status before the law and government, also have the right to obtaining justice, equal treatment and legal protection, as well as the right, to demand justice and truth by applicable law without discrimination based on race, religion, divinity, position and society class (4).

The birth of Act Number 18 of 2003 concerning the Advocate, enacted on April 5, 2003 and immediately applicable on the date of enlawment, confirms the existence of professional advocate in Indonesia as one of the law enforcement that is free and independent by law and regulations (Article 5) (5). Hopefully, there will be a legislation specifically set as an umbrella for legal profession, such as lawyers and other law enforcement officials, namely judges, prosecutors, police ${ }^{6}$ (Karjadi \& Raden, 1988). With this legislation, it gives confidence as well as respect as equal partners in the law enforcement process $(7,8)$. However, the big question is how the existence of professional advocate in Indonesia before and after the enlawment of Act Number 18 of the Advocate, as well as any constraints that occur in its implementation.

\section{a. Before Applicability of Act Number 18 Of 2003 Concern- ing Advocate.}

The rule of law relating to the profession of advocate before the Birth of Act Number 18 of 2003 concerning the Advocate, scattered in various laws, such as Act Number 1 of 1946 on the Law of Criminal Code, Act Number 1 of 1950 on the Supreme Court, Emergency Act Number 1 of 1951 governing measures temporarily hold unity power structure and events Civil Court, and Herziene Indlandsch Reglement (HIR).

\section{Act Number 1 of 1946}

In 1946, the government of the Republic of Indonesia (RI) issued Act Number 1 of 1946 on the rule of Criminal Law. In the legislation it is set on the position and the advocates Procureur and those who provide legal assistance. In the Bill, the government determined that the criminal law applicable to the draft Penal Code in force dated March 8, 1942 which also means that for the Criminal Law applies Werboek van Strafrecht voor Nederlands Indie modified by Japanese occupation army. Act Number 1 of 1946 is the changes and additions of the Wetboek van Strafrecht voor Nederlandsch Indie later named Wetboek van Strafrecht translated the Code of Penal (Penal Code). Act Number 1 of 1946 provides the power to adapt the Criminal Code, namely the provisions contained in Article $\mathrm{V}$ which states that: "the criminal provisions, which wholly or partially executed or contrary to the position of the Republic of Indonesia as an independent state, or no meaning again, must be entirely or partially while not applicable.

"Applicability of the Act Number 11946 Issuer pursuant to section II Transitional Provisions of the Act of 1945 which reads: 
"All of the State and the existing legislation still has not been held directly apply for a new one in accordance with this Constitution". Further in article 1 of Act Number 1 of 1946 confirmed that the necessary deviate from Presidential Regulation dated October 10 1945 Number 2 stipulates that the regulations for the current Criminal Law is the regulation of existing criminal law on 8 March 1942. Furthermore, the existing criminal law on March 8 1942 and is a relic of the Dutch government is declared invalid, then so shall also apply "Determination of the King" dated May 4, 1926 Number 251 in conjunction with 486 of Regulation How to Do / Running Punishment with the Terms. In Chapter I, Part II, Section 3, paragraph 3 stipulated that 'People are punished and those who are obliged to provide assistance, may investigate any letter before the commencement of the examination'. This rule applies on the Supreme Court and High Courts for the Advocate and Procureur prLawices in the area of Indonesia. It is explained that convicted men had to authorize the investigation of the letter. Furthermore, in article 4 paragraph 4 stipulated that persons convicted and those who are required to provide legal assistance to be heard if they are present. As for the Supreme Court and High Courts, the convicted men should be assisted by an advocate or Procureur in the area of Indonesia and just about the Assembly Judiciary and others by an especially authorized for that as Counsel. Then, chapter 5, verse 3 was determined that the content of the decision was notified to the person who was sentenced immediately on the orders of civil servants mentioned in Article 1, as he was given a copy of the decision to give to those who are required to provide assistance and also to people who at that decision freed from him. Furthermore, Article 6 paragraph 2 stated that within three weeks after the decision was notified, the condemned not present, it can use or get someone with his authority by using the letter of attempts allowed to fight the decision in the face of the judge concerned. That the monitoring of people who provide legal aid or people authorized and to appoint agencies and people who may be governed aid was set by law(Gazette of 1926 Number 487).

\section{Act Number 1 of 1950}

Act Number 1 of 1950 regarding the Supreme Court, came into force on May 9, 1950, governing the composition of Power and Roads Courts Supreme Court of Indonesia. Article 42 gives the term "legal aid" with the words "Defender".

Article 113 paragraph 1 of Act Number 11950 asserted that: "Request for examination of an appeal must be submitted by letter or verbally by the applicant or his representative who deliberately empowered to apply it to the clerk of the court or the judge who conducted the decision determination or Lawion filed cassation examination is in Java and Madura within three weeks and outside Java and madura, within six weeks after the verdict that strength has remained, notified to the applicant ". While the second paragraph reads: "The request was by him, are written in a statement signed by the court clerk, and if it can also be the applicant or his Vice-certificate which must be attached to the letter of the case investigation and recorded in the list". The contents of the provisions pasa 113 paragraph 1 in the case of a civil case has similarities with the sound of article 122, paragraph 1 , the only difference Article 113 paragraph 1 only to civil matters, while Article 122 paragraph 1 of the criminal case. According to the law above, the Supreme Court has the power to supervise the operations of the supreme court (Article 12) and the behavior of Law on the courts and judges in the trial, carefully watched by the Supreme Court. Highest Supervision is also carried out by the Supreme Court against the legal aid providers or advocates / lawyers and notaries. On the surveillance provided for in article 133, which reads: "Supervision of the highest on the Notary and Lawyers conducted by the Supreme Court."

\section{Emergency Act Number 1 of 1951}

Emergency Act Number 1 of 1951 regulates temporary measures to organize the unity of the pecking order and civil court event. The important thing about this law is a provision mentioned in article 6, paragraph 1 , which provides: "That when these regulations come into force by any Court by any Attorney to him, and by all the High Court in the area of Indonesia" Indonesia Regulation updated" (staatsblad of 1941 number 44) that it is possible to be taken as guidance on the criminal case show civilian with changes and additions". Emergency Act determines the re-enLawment "Herziene Inlandsch Reglement" (Staatsblad Of 1941 Number 44) in the Republic of Indonesia at that time was used as a guide in the Criminal Procedure Code Civil.

\section{Herziene Inlandsch Reglement (HIR)}

In conjunction with the duties and obligations of lawyers, Procureur, and providers of legal aid before the court set up in several chapters HIR like:

- Section $83 \mathrm{~h}$ paragraph 6 , which states that: "If a person is accused guilty of doing anything that can be punished with the death penalty, then magistraat let asked him, would he assisted in court by a General Counsel or a lawyer ". The provisions of article 83 paragraph 6 above is narrower because it is limited to crimes that can be punished with the death penalty. In fLaw, when compared with article 120 Reglement op de Strafvordering (RSV) is Reglement Criminal Procedure Code for VAB Raad Justitie and Hooggerechtshof wider scope. In Article 120 RSV, is not limited to a crime that can be punished with the death penalty, but in all cases the crime the defendant is authorized to have recourse to a lawyer as a defense in the case.

- Article 120 RSV states that: "Each defendant competent to be assisted by an advocate in the examination in front of a judge. If the defendant has no defense, then on expectation judge may appoint an advocate or Procureur seconded to the Raad van Justitie.

- "Article 250, paragraph 5 HIR asserts that:" If the accused was brought to court for a crime, punishable by the death penalty and the accused, either in the examination by justice officer set out in paragraph 6 of article $83 \mathrm{~h}$, expressed his will so he was at the time the trial was assisted by a scholar of law or a lawyer to provide assistance. The chairman showed the determination letter to the members of the district court jurist, scholar or an bachelor of law were under his orders, or in a lawyer or other legal experts who said it was willing to do the job ". In Article 250 paragraph 5 above stated that the possibility of going to get a defense counsel appointed by the judge at the request of the defendant in advance Raad van Justitie or the District Court is limited to cases which may lead to the death penalty alone, as long as there lawyers or other defenders who are willing.

- Article 254 paragraph 1 HIR asserts that: "In the trial each accused is entitled to be assisted by a defense to defend him". The provisions of article 254, paragraph 1 above HIR assert their rights of the accused to defend its case by a defense at trial. As has been affirmed in Article 250 HIR any a difference Reglemen system of Criminal Procedure (RSV) with the system in HIR about the possibility of appointing a judge, an advocate, legal adviser to the defendant, if the defendant does not have its own defense. The difference is because the legislator wants a simple procedure in Landraad, so if the case investigation is deemed necessary the accused be defended by an advocate or lawyer whose costs are generally not paid by the defendant if he cannot afford. The interests of the accused is considered reasonably assured at the head of the court or the presiding judge who examined. Which opened the possibility in paragraph 5 of Article 250 HIR defendants were prosecuted for crimes that can lead to the 
death penalty may apply for aid defense counsel appointed by the judge if he himself has no defenders. In this regard, the government has provided legal aid funding for those who cannot afford, so the defense or the defense counsel appointed by the court will accept the reward, although not much.

- Article 123 HIR asserts that if required by the litigants then the parties may be assisted or represented by a proxy, which is authorized to do it with a special power of attorney unless the person authorizes it (any) present themselves. This provision also confirms that to judge with different civil procedure in advance Raad van Justitie, the two blades litigants are required to use the help of an advocate or Procureur.

- Law No. 19 of 1964 on Basic Provisions on Judicial Power. In paragraph 26 contained provisions governing legal aid, which affirmed that the rights of every person who has a case for legal aid shall be regulated by law.

\section{b. After Applicability of Act Number 18 of 2003 Concerning the Advocate.}

Prior to the release of Act Number 18 of 2003 concerning the Advocate, the use of the term "Advocate" in Law there has been no standard for the profession. In various provisions of the legislation of any inconsistency, for example Act Number 14 of 1970, as has been replaced by Act Number 35 of 1999, and was replaced again by Act Number 4 of 2004 as well as the latter is replaced by Act Number 48 of 2009, regarding the power of Justice, to use the term legal aid and lawyers. Act Number 8 of 1981 on the Law of Criminal Law (Penal Code), Act Number 2 of 1986 on General Courts, Act Number 5 of 2004 on the Amendment to Act Number 14 of 1985 regarding the Supreme Court uses the term "Law Advisor". Ministry of Law and Human Rights Attorneys use the term, and the High Court used the term "Advocate" and "Lawyer". Then Act Number 18 Year 2003 concerning The Advocate use the term "Advocate", in addition there is also a call to the term by the defense.

Advocate comes from the Dutch language, i.e., advocaat, which means the person who is providing legal services. The services are provided either inside or outside the courtroom. Understanding advocate according to Black's Law Dictionary is to speak in favor of or defend by argument (speaking for the benefit of or defended by arguing for someone). As for those who work as advocate is one who assists, defends, or pleads for another. One who renders legal advice and aid, pleads the cause of another before a court or a tribunal, a counselor (someone who helps, maintain, or defend for others. A person who provides legal advice and help defend the interests of others before the court or siding, a consultant).

The meaning of advocate term under Article 1 paragraph (1) of Act Number 18 of 2003 concerning The Advocate is the person who is giving legal services, both inside and outside the court that meets the requirements under the provisions of this law. Frans Hendra Winata explained that the employment legal counseling (legal consultant) has been included in it assist, help, and declare one's guilt or innocence in the courts and other public siding. Definition of Legal Counsel under Article 1, point 13 Book of LawCriminal Procedure is someone who meets the conditions stipulated by or based legislation to provide legal assistance. The formulation of Article 1, point 13 explained, however, that to be a legal advisor should be someone who meets the requirements prescribed by law. Legal Aid term previously impressed bias, emphasized by Law Number 18 of 2003 concerning Advocates, in Article 1 point 9, which defines it as: "legal services provided by lawyers free of charge to clients who cannot afford". In addition to the rights granted by law to advocate for the profession and ask honorarium in exchange for legal services received by advocates by agreement with the client, as referred to in Article 1 paragraph 7 of Act Number 18 of 2003 concerning The Advocate. Advocates are also given the burden of moral responsibility to provide legal assis- tance to the justice seekers who cannot afford. It is mentioned in Article 22 paragraph (1) and (2) of Act Number 18 of 2003.

According to the Article 2 (1) Act Noumber 18 of 2003 concerning The Advocate assert that what is meant by "high educational background of law of a law graduate, faculty of sharia, colleges of military law and police science colleges. As for the position and the role of lawyers in relation to judges and prosecutors in criminal justice (criminal justice system) of the attitudes and judgment of each party in a criminal trial is that judges foundation on its position and objective assessment is also an objective, while the public prosecutor representing the State and society-ranking reject the position that subjective but an objective assessment. This is different to advocate the foundation on which a subjective position because it represents the interests of the suspect / defendant or client, and a subjective judgment anyway. Nonetheless, advocates was based legitimacy is rooted in ethics, he must have an objective assessment of the events in the trial.

\section{Advocate Organization}

The enlawment of Act of the Republic of Indonesia Number 18 of 2003 concerning The Advocate is the expectation of a long delayed during the 58 years since the independence of the Republic of Indonesia, the laws governing the profession of advocate, free, independent and responsible, for the the implementation of a fair trial and legal certainty for all justice seekers in upholding the law, truth, justice, and human rights $(5,9)$. It is hard with logic when expected independent professional advocates but the process of recruitment, appointment, taking the oath to exist under the supervision of the judiciary or the legislature, either the High Court / Supreme Court and the Ministry of Law and Human Rights. Often complaints from advocates who have problems with the administration of his profession when he was in trouble with the judges and prosecutors, while on the other hand he carries the load as the attorney or counsel of the client he should defend responsibly (10) Then the Act of the Republic of Indonesia Number 18 of 2003 concerning The Advocate mandates the formation of Advocate Organization, the singular and the right to conduct the process of recruitment, appointment, extending the license to practice Law, as well as independent supervision without interference from the power of the State.

According to Article 32 paragraph (4 ) Act Number 18 of 2003 concerning The Advocate, Advocate Organization must be established no later than two years since the law was enlawed. Many people are dubious at Advocates can meet the deadlines referred to by law. In reality, within about 20 months since the existence of Advocate Law, in December 21, 2004, the Indonesian Advocates agreed to declare Perhimpunan Advokat Indonesia/Indonesian Advocates Association (Peradi). Agreement to establish Peradi preceded by a long process. Article 32 paragraph (3) of Act Number 18 of 2003 stated that while the duties and authority of Advocate Organization is run jointly by Ikatan Advokat Indonesia/the Association of Indonesian Lawyers (Ikadin), Asosiasi Advokat Indonesia/Indonesian Advocate Association (AAI), Ikatan Penasihat Hukum Indonesia/the Association of Legal Counsel Indonesia (IPHI), Himpunan Advokat dan Pengacara Indonesia/the Association of Advocates and Lawyers Indonesia (HAPI), Serikat Pengacara Indonesia/Indonesia Lawyers Union (SPI), Asosiasi Konsultan Hukum Indonesia/the Association of Indonesian Legal Consultants (AKHI), Himpunan Konsultan Hukum Pasar Modal/the Capital Market Legal Consultants Association (HKHPM) and Asosiasi Pengacara Syariah Indonesia/Syariah Lawyers Association of Indonesia (APSI). To run the task in question, eight Advocate organizations above, on June 16, 2003, agreed to use the name of Komite Kerja Advokat Indonesia/the Working Committee of Indonesian Advocates (KKAI) and finally agreed to form Peradi. KKAI has completed a number of preparations, the first is to do a verification to ascertain the name and number of Advocates in Indonesia. The verification process in line with the implementation of Article 32 paragraph (1) of the Advo- 
cate Law which states that advocates, legal advisors, and legal consultants which has been raised during the enLawment of the law is expressed as the Advocate as stipulated by law. A total of 15,489 out of 16,257 Advocate applicants met the verification requirements. Advocates have been members of Peradi through their memberships in a professional organization based on eight in KKAI.

As part of the verification process, also formed a membership numbering system of the Advocate for national sphere, also known as Advocate Registration Number. Furthermore, those who pass the verification requirements are also given Kartu Tanda Pengenal Advokat/Identification Card of Advocate (KTPA). In the past, it was issued by the high court where the advocate resides. The new KTPA was launched on March 30, 2004. The second preparation was the establishment of the Organization Committee in order to prepare draft Advocate Organization in accordance with the circumstances in Indonesia. Commissioned working paper on the organization then was used as the basis to determine the shape and composition of the Advocate Organization that is acceptable to all parties. Other preparations have been completed by KKAI, the formation of the Certification Commission. The Commission prepares matters concerning the appointment of a new Advocate. To be appointed as Advocate, in addition to having a high educational background in law, the Advocate of Law required that every candidate to attend a special training, apprenticeship for two years in the office of an advocate, and then passed the test organized Advocate Advocate Organization. The regulations for the above requirements prepared by the Commission.

After its formation, Peradi has implemented several fundamental decisions. First, Peradi has formulated procedures for foreign Advocate recommendations to work in Indonesia. Second, Peradi has established the Honorary Board while domiciled in Jakarta and will be continued by forming a Permanent Honorary Board. Establishment of an Honorary Council in other areas is currently a priority by Peradi. Third, the Commission has established Peradi Profession Advokat Indonesia (KP2AI) education. The Commission is responsible about the provision of special education and education for prospective legal Advocate sustainable for the Advocate. Peradi existence as an Advocate Organization as mandated by the Advocate Law, supported by the letter of the Supreme Court No. KMA / 445 / VI / 2003, which contains the removal procedure, mutations are required to notify the advocate: District Courts; Advocates organization (in this case KKAI), and local government. Letter of the Supreme Court Number 07 / SEK / 01/2007, regarding dissemination Advocate Identification Card (KTPA) recently, also called the Peradi as an Advocate Organization will issue new KTPA. Letter of the Supreme Court No .: MA / KUMDIL / 01 / III / K / 2007, addressed to the Chairman of the High Court over Indonesia, as Circular No. 01 Year 2007 on Guidelines Oath Taking Advocate, in which explicitly mentions Peradi as an Advocate Organization.

\section{References}

[1] Ishaq SH, Hum M. Pendidikan Keadvokatan. Sinar Grafika, Jakarta; 2010.

[2] Sinaga VH. Dasar-Dasar Profesi Advokat. Jakarta: Erlangga. 2011

[3] Indonesia PA. Kitab Advokat Indonesia. Perhimpunan Advokat Indonesia; 2007.

[4] Hamzah A. Pengantar Hukum Acara Pidana Indonesia. Ghalia Indonesia; 1984

[5] Desika Ermawati Putri NM, Tjatrayasa I. IMPLIKASI PUTUSAN NOMOR 26/PUU-XI/2013 MENGENAI JUDICIAL REVIEW PASAL 16 UNDANG-UNDANG NOMOR 18 TAHUN 2003 TENTANG ADVOKAT TERHADAP PERLINDUNGAN HUKUM PROFESI ADVOKAT. Kertha Wicara. 2015;4(01).

[6] Karjadi M, (Raden.) S. Kitab Undang-Undang Hukum Acara Pidana dengan penjelasan resmi dan komentar (serta Peraturan Pemerintah RI No. 27 tahun 1983 tentang pelaksanaanya).
Politeia; 1988.

[7] Abdullah J. KODE ETIK PROFESI ADVOKAT. YUDISIA J Pemikir Huk dan Huk Islam. 2015;4(1).

[8] Arto AM. Praktek Perkara Perdata Pada Pengadilan Agama. Pustaka Pelajar; 1996.

[9] Winarta FH. Advokat Indonesia: citra, idealisme, dan keprihatinan. Pustaka Sinar Harapan; 1995.

[10] Amir AY. Strategi Bisnis Jasa Advokat. Yogyakarta: Navila Idea; 2008 